\title{
INTRA-UTERINE DEVICE AND EMBRYONIC SURVIVAL IN THE RAT
}

\author{
K. F. DeBOER, L. L. ANDERSON AND R. M. MELAMPY \\ Department of Animal Science, Iowa State University, \\ Ames, Iowa 50010
}

(Received 31st Fuly 1969, revised 23rd September 1969)

The mode of action of intra-uterine devices (IUDs) has been postulated by several investigators to involve a pharmacologically active substance capable of inhibiting the uterine decidual response or of actively cytolysing the preimplantation blastocysts (Marston \& Chang, 1965; Marston \& Kelly, 1969; Doyle \& Margolis, 1963; Batta \& Chaudhury, 1968a, b; Parr, Schaedler \& Hirsch, 1967). An investigation of the effect of uterine secretions on ovarian function and embryonic survival in the rat is reported here.

Rats (180 to $250 \mathrm{~g}$; Holtzman Co.) were maintained as previously described (Anderson, Melampy \& Chen, 1967). Daily vaginal smears were taken. Day 1 was characterized by the appearance of spermatozoa in mated animals. In the first series of experiments (Table 1), laparotomies were carried out under ether anaesthesia, using clean but not sterile technique, at all stages of the oestrous cycle. A silk thread (no. 5-0) was inserted midway in the right horn of the uterus according to the method of Parr et al. (1967). In the same animals, a passage was made with a scalpel (blade no. 11) between the uterine horns by incising the left side of the uterus, $2 \mathrm{~mm}$ anterior to the cervical os, through which a pair of iris scissors was inserted (Group A, Table 1). By cutting and puncturing the thin intercornual septum several times, a permanent supracervical passage was effected. This uterine incision was not sutured. In seven other animals (Group B, Table 1), this uterine passage was made, but no IUD was inserted in the right horn. Thirteen rats on which no operation was performed acted as controls (Group $\mathrm{G}$, Table 1). All rats were mated, beginning I week after surgery. They were killed on Day 13 and the number of living and resorbing embryos was recorded. The patency of the interuterine passage was tested by injecting $1 \mathrm{ml}$ saline into one horn. Only those animals in which saline passed readily into the opposite horn were included in the experimental group.

At autopsy, there were no embryos in the IUD-bearing (right) horn. However, the opposite horn in rats with a passage between the horns exhibited a highly significant $(P<0.01)$ reduction in the number of embryos (average 0.7 ; Table 1). The control animals contained a normal number of live embryos (average 6.6). Thus, an IUD in one uterine horn produced a drastic bilateral effect by reducing embryonic survival rates, presumably by action of some substance diffusing from the IUD horn to affect the other horn. Batta \& 
Chaudhury (1968b), Wood \& Kirby (1968) and Marston \& Kelly (1969) have also performed similar experiments, though with a larger and more traumatic uterine anastomosis, and have reached a similar conclusion. Wood \& Kirby (1968) found that this factor would not diffuse through myometrial tissue but required luminal continuity. In the results presented here, however, there was a reduction $(P<0.05)$ in embryonic survival rates in rats which received shamoperations (Group B, Table 1) as compared with those on which no operation was performed (Group G). Other workers have reported similar findings (Batta \& Chaudhury, 1968b; Marston \& Kelly, 1969).

To determine if the horn with the IUD contains an active principle which reduced embryonic survival, the horn having the IUD was flushed and the

TABLE 1

BILATERAL EFFEGT OF AN IUD ON EMBRYONIC SURVIVAL WHEN A PASSAGE EXISTS BETWEEN UTERINE HORNS IN THE RAT

\begin{tabular}{|c|c|c|c|c|c|c|}
\hline \multirow{2}{*}{ Group } & \multirow{2}{*}{ Treatment } & \multirow{2}{*}{$\begin{array}{l}\text { No. of } \\
\text { rats }\end{array}$} & \multicolumn{2}{|c|}{$\begin{array}{c}\text { Living embryos } \\
\text { in horn } \\
\text { opposite IUD }\end{array}$} & \multicolumn{2}{|c|}{$\begin{array}{l}\text { Embryonic survival in } \\
\text { contralateral (left) horn } \dagger\end{array}$} \\
\hline & & & No. & Mean \pm S.E. & Mean $\%$ & Mean arcsin and S.E. \\
\hline B & $\begin{array}{l}\text { IUD in right horn; } \\
\text { passage between } \\
\text { horns } \\
\text { No IUD in either } \\
\text { horn: passage }\end{array}$ & 8 & 6 & $0.7 \pm 0.5$ & $11 \cdot 5$ & $11 \pm 4 \cdot 6^{*}$ \\
\hline C & $\begin{array}{l}\text { between horns } \\
\text { Unoperated controls }\end{array}$ & $\begin{array}{r}7 \\
13\end{array}$ & $\begin{array}{l}33 \\
86\end{array}$ & $\begin{array}{l}4 \cdot 7 \pm 0.9 \\
6 \cdot 6 \pm 0 \cdot 6\end{array}$ & $\begin{array}{l}60 \cdot 0 \\
83 \cdot 5\end{array}$ & $\begin{array}{l}49 \pm 10 \cdot 0^{* *} \\
68 \pm 4 \cdot 1\end{array}$ \\
\hline
\end{tabular}

* Significant at 0.01 level by analysis of variance.

** Significant at 0.05 level by analysis of variance.

$\dagger$ Embryonic survival rate was calculated as: No. living embryos/no. corpora lutea $\times 100$.

fluid collected from that horn was injected into the opposite, intact horn of the same rat on Day 3 or 4 . For these experiments, 115 rats were randomly allotted to six groups (Table 2). An IUD was inserted into the right uterine horn of rats in Group 1, and no operation was performed on the animals in Groups 2 to 6 . After three oestrous cycles, all rats were mated. On Day 3 or 4 , rats in Groups 1 to 5 , anaesthetized with ether, were subjected to laparotomy using aseptic techniques. In the rats in Group 1, the middle portion of the right horn, which contained the IUD, was occluded with small bulldog clamps, and $0.08 \mathrm{ml}$ medium TC 199 (Difco) was injected. The same amount of fluid was injected into the lumen of the right horn, which had no IUD (Group 2). After flushing the medium six to eight times, $0.05 \mathrm{ml}$ of it, now containing uterine fluid and débris, was withdrawn with a 23-gauge needle. This fluid was then injected through a 26-gauge needle into the opposite (left) horn at the tubo-uterine junction of the same animal (Groups 1 and 2). Rats in Group 3 received $0.05 \mathrm{ml}$ TG 199 medium in the left horn. Uterine fluid $(0.05 \mathrm{ml})$ was aspirated from oestrous females and injected into the left horn of mated rats at Day 3 or 4 (Group 4). The fresh uterine fluid was injected within 5 min of collection and its contents were not analysed. A 26-gauge hypodermic needle was inserted into 
the uterine lumen of the left horn of the mated rats in Group 5 at laparotomy but no fluid or medium was injected. All operations were carried out between 12.00 and 17.00 hours on either Day 3 or 4. The rats in Group 6 received no operative treatment.

There was a reduction in embryonic survival by Day 13 in rats which received sham-operations on Day 4 (Group 5) as compared with those on which no operation was performed (Group $6 ; P<0.05$ ). Also, there was a significant difference $(P<0.05)$ in embryonic survival between animals after sham injection (Group 5) and after injection of fluid (Groups 2 and 3) on Day 4. Thus,

TABLE 2

EFFEGT OF INTRA-UTERINE INJEGTIONS OF UTERINE FLUIDS AND PHYSIOLOGICAL MEDIA ON EMBRYONIC SURVIVAL IN THE RAT

\begin{tabular}{|c|c|c|c|c|c|c|}
\hline \multirow{2}{*}{ Group and treatment* } & \multirow{2}{*}{$\begin{array}{l}\text { Day of } \\
\text { injection }\end{array}$} & \multirow{2}{*}{$\begin{array}{l}\text { No. of } \\
\text { rats }\end{array}$} & \multicolumn{2}{|c|}{$\begin{array}{l}\text { Living embryos } \\
\text { in injected (left) horn }\end{array}$} & \multicolumn{2}{|c|}{$\begin{array}{l}\text { Embryonic survival } \\
\text { in injected horn }\end{array}$} \\
\hline & & & Total no. & Mean士S.E. & Mean \% & Mean arcsin and $S . E$. \\
\hline $\begin{array}{l}\text { 1. TC medium } 199 \dagger \\
\text { flushings from horn with } \\
\text { IUD }\end{array}$ & $\begin{array}{l}3 \\
4\end{array}$ & $\begin{array}{l}12 \\
10\end{array}$ & $\begin{array}{r}16 \\
0\end{array}$ & $\begin{array}{l}1 \cdot 3 \pm 0 \cdot 7 \\
0 \cdot 0\end{array}$ & $\begin{array}{r}23 \\
0\end{array}$ & $15 \pm 7 \cdot 2$ \\
\hline $\begin{array}{l}\text { 2. TC medium } 199 \dagger \\
\text { flushings from intact } \\
\text { horn }\end{array}$ & $\begin{array}{l}3 \\
4\end{array}$ & $\begin{array}{l}13 \\
10\end{array}$ & $\begin{array}{r}27 \\
4\end{array}$ & $\begin{array}{l}2 \cdot 1 \pm 0.7 \\
0.4 \pm 0.4\end{array}$ & $\begin{array}{r}41 \\
7\end{array}$ & $\begin{array}{l}34 \pm 9 \cdot 0 \\
13 \pm 11 \cdot 7\end{array}$ \\
\hline 3. TC medium $199 \dagger$ & $\begin{array}{l}3 \\
4\end{array}$ & $\begin{array}{r}10 \\
9\end{array}$ & $\begin{array}{r}19 \\
8\end{array}$ & $\begin{array}{l}1.9 \pm 0.8 \\
0.9 \pm 0.3\end{array}$ & $\begin{array}{l}33 \\
10\end{array}$ & $\begin{array}{l}29 \pm 10 \cdot 7 \\
13 \pm 4 \cdot 4\end{array}$ \\
\hline $\begin{array}{l}\text { 4. Uterine fluid from intact } \\
\text { horn of oestrous females }\end{array}$ & $\begin{array}{l}3 \\
4\end{array}$ & $\begin{array}{l}9 \\
8\end{array}$ & $\begin{array}{r}21 \\
4\end{array}$ & $\begin{array}{l}2 \cdot 7 \pm 0.7 \\
0.5 \pm 0.3\end{array}$ & $\begin{array}{r}37 \\
8\end{array}$ & $\begin{array}{l}33 \pm 8 \cdot 8 \\
11 \pm 4 \cdot 0\end{array}$ \\
\hline $\begin{array}{l}\text { 5. Laparotomy and inser- } \\
\text { tion of hypodermic } \\
\text { needle into uterine } \\
\text { lumen }\end{array}$ & $\begin{array}{l}3 \\
4\end{array}$ & $\stackrel{8}{11}$ & $\begin{array}{l}40 \\
21\end{array}$ & $\begin{array}{l}5 \cdot 0 \pm 1 \cdot 0 \\
2 \cdot 0 \pm 0 \cdot 6\end{array}$ & $\begin{array}{l}78 \\
49\end{array}$ & $\begin{array}{l}67 \pm 10 \cdot 8 \\
38 \pm 9 \cdot 4\end{array}$ \\
\hline 6. Unoperated controls & - & 15 & 86 & $5 \cdot 9 \pm 0.6$ & 80 & $67 \pm 3 \cdot 6$ \\
\hline
\end{tabular}

* Total volume of fluid injected was $0.05 \mathrm{ml}$ in each animal.

$\dagger$ Difco Laboratories, Detroit, Michigan, U.S.A.

injection of this quantity of fluid into the uterine lumen had an additional detrimental effect upon embryonic survival.

When the uterine fluid or TG 199 medium (Groups 1 to 4) was injected into the uterine lumen on Day 3, embryonic survival was reduced as compared with that in the rats of Group $5(P<0.05)$ or Group $6(P<0.05)$, but embryonic loss was not as extensive as that found at Day 4 . Embryonic survival rates of rats given uterine fluid or TC 199 medium on Day 3 were similar in Groups 1 to 4 $(P>0.05)$. Thus, uterine fluid (Group 4), TG 199 medium (Group 3), uterine fluid from an intact horn (Group 2), and uterine fluid from a horn containing an IUD (Group 1) reduced embryo survival by a similar amount. These results are not in agreement with Batta \& Chaudhury (1968a). There is a suggestion that the fluids obtained from the horn with the IUD (Group 1) on Day 3 contained anti-fertility activity (23\% embryonic survival) as compared with the injection of fluid from horns not having an IUD (Group 2; $41 \%$ embryonic survival), though these differences were not statistically significant. 
It appears, from the results of the first experiment (Table 1) and those of other workers, that an anti-fertility factor(s) originates in the IUD-bearing uterus and also that this substance diffuses from one uterine horn to another. Results from the second experiment (Table 2), however, involving an attempt to recover this factor from an IUD-bearing horn and to inject it into a normal horn, failed to give clear evidence of such a factor. Surgical manipulation may have masked the anti-fertility effect of the substances obtained from IUD-bearing uteri. McLaren (1968) has reported that $0.05 \mathrm{ml}$ saline injected into the uterus of mice on Day 4 prevented blastocysts from surviving. Batta \& Chaudhury (1968a) transferred uterine fluid from IUD-containing horns of oestrous rats into pregnant horns on Days 2 and 4, and they observed a sharp reduction in embryonic survival. However, transfer of uterine fluid from horns having no IUD had little effect on embryonic survival at these times. The discrepancy between the results reported here and those of Batta \& Chaudhury (1968a) may be explained by differences in experimental techniques. In addition, autopsies were carried out on the rats of Batta \& Chaudhury (1968a) on Day 10, a stage at which it is sometimes difficult to distinguish between viable and non-viable embryos, whereas the animals in experiments reported here were examined on Day 13, when substantial numbers of resorbing sites were found.

This study was supported, in part, by Grants HD 01168-10 and HD 00184-02 from the National Institutes of Ghild Health and Human Development, National Institutes of Health, Bethesda, Maryland, U.S.A. This is Journal Paper No. J-6330 of the Iowa Agriculture and Home Economics Experiment Station, Ames, Iowa. Projects No. 1325 and 1712.

\section{REFERENCES}

Anderson, L. L., Melampy, R. M. \& Chen, C. L. (1967) Uterus and duration of pseudopregnancy in the rat. Archs Anat. microse. 56, Suppl. 3-4, 373.

Batta, S. K. \& Chaudhury, R. R. (1968a) The anti-implantation property of intraluminal fluid in rats with an intra-uterine silk thread suture. F. Reprod. Fert. 16, 145.

Batta, S. K. \& Chaudhurry, R. R. (1968b) Antifertility effect of an intra-uterine silk thread suture in rats with a connection between the two uterine horns. F. Reprod. Fert. 16, 371.

DoyLE, L. L. \& MARgolis, A. J. (1963) Intrauterine foreign body: Effect on pregnancy in the rat. Science, N.Y. 139, 833.

Marston, J. H. \& Chang, M. C. (1965) Action of intra-uterine foreign bodies in the rat and rabbit. Proc. 2nd int. Conf. on Intra-uterine Contraception. N.Y. Excerpta Med. Int. Congr. Ser. 86, 242.

Marston, J. H. \& Kelly, W. A. (1969) The effect of uterine anastomosis on the action of an intrauterine device in the rat. $\mathcal{F}$. Endocr. 43, 95.

MCLAREN, A. (1968) A study of blastocysts during delay and subsequent implantation in lactating mice. 7. Endocr. 42, 453.

Parr, E. L., Schaedler, R. W. \& Hirsch, J. G. (1967) The relationship of polymorphonuclear leukocytes to infertility in uteri containing foreign bodies. F. exp. Med. 126, 523 .

Wood, J. C. \& KIRBY, D. R. S. (1968) The effect of uterine anastomosis on the action of the IUGD in rats. Am. F. Obstet. Gynec. 102, 1041. 